\section{History of Controlled Environment Horticulture: Ancient Origins}

Jules Janick

Department of Horticulture and Landscape Architecture, Purdue University, West Lafayette, IN 47907

\section{Harry Paris}

Department of Vegetable Crops \& Plant Genetics, Agricultural Research Organization, Newe Ya'ar Research Center, P.O. Box 1021, Ramat Yishay 30-095, Israel

Additional index words. Columella, Pliny the elder, proto-greenhouse, specularia, Tiberius

Abstract. In the first century CE, two Roman agricultural writers, Lucius Junius Moderatus Columella and Gaius Plinius Secundus (Pliny the Elder), referred to proto-greenhouses (specularia) constructed for the Emperor Tiberius (42 BCE-37 CE) presumably adjacent to his palace, the Villa Jovis on the Isle of Capri. Pliny stated in Historia Naturalis (Book 19, 23:64) that the specularia consisted of beds mounted on wheels that were moved into the sun, and on wintry days withdrawn under the cover of frames glazed with transparent stone (lapis specularis) to provide fruits of cucumis. According to Pliny, this was "a delicacy for which the Emperor Tiberius, had a remarkable partiality; in fact there was never a day on which he was not supplied it." The cucumis fruits described by Columella and Pliny, long mistranslated as cucumbers, Cucumis sativus, were in fact long-fruited melons, Cucumis melo subsp. melo Flexuosus Group. They are known today as vegetable melons, snake melons, and faqqous, and were highly esteemed in Rome and ancient Israel.

The origins of controlled environment horticulture are to be found in the Roman proto-greenhouse constructed to grow cucumis for Rome's second emperor, Tiberius Caesar Augustus (42 BCE-37 CE) (Fig. 1A). These structures were probably located adjacent to his palace, the Villa Jovis, on the Isle of Capri (Fig. 1B). Tiberius, emperor from 14 to $37 \mathrm{CE}$, reigned during the crucifixion of Jesus, as mentioned in the New Testament (Luke 3:1). The verse "Render therefore unto Caesar the things which are Caesar's and unto God the things that are God's" (Matthew 22:17), refers to Tiberius.

\section{Ancient Roman Sources}

Two surviving first-century Roman texts, De Re Rustica (On Agriculture) written by Lucius Junius Moderatus Columella, 4 BCE to $70 \mathrm{CE}$ (Fig. 2A), and Historia Naturalis (Natural History) written by Gaius Plinius Secundus, 23 to $79 \mathrm{CE}$, known as Pliny the Elder (Fig. 2B), provide contemporary details

Received for publication 27 July 2021. Accepted for publication 2 Sept. 2021.

Published online 13 January 2022

This manuscript is based on a workshop sponsored by the History of Horticulture Working Group at the Annual Conference of the American Society for Horticultural Science, 2019.

J.J. is the corresponding author. E-mail: knemali@purdue.edu.

This is an open access article distributed under the CC BY-NC-ND license (https://creativecommons. org/licenses/by-nc-nd/4.0/). water; then, when the seeds have come up, he should place the baskets in the open air on

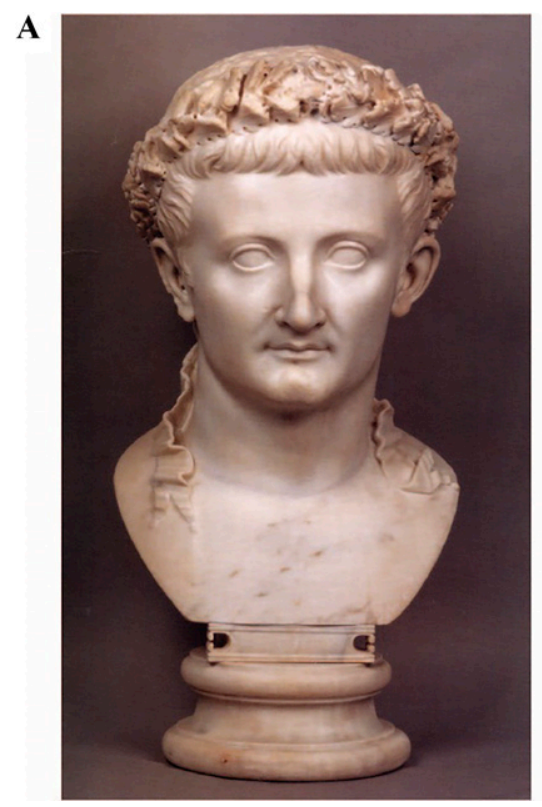
Capri. warm and sunny days near a building, so that they may be protected from any blasts of wind; but if it is cold and stormy, he should bring them back under cover and continue to do so until the spring equinox is over. $\mathrm{He}$ should then sink the whole baskets into the ground. He will then have early fruits. It is also possible, if it be worth the trouble, for wheels to be put under larger vessels, so that they may be brought out and then taken indoors again with less labour. In any case the vessels ought to be covered with slabs of transparent stones [specularibus] so that even in cold weather, when the days are clear, they can safely be brought out into the sun. By this method Tiberius Caesar was supplied with cucumis during almost the whole year." De Re Rustica X1. III. 52-53 (Forster and Heffner, 1955).

HistorIA NATURALIS. "Belonging to the class of cartilaginous plants and growing on the surface of the ground is the cucumber [cucumis] for which the emperor Tiberius had a remarkable partiality: in fact, there was never a day which he was not supplied with it, as his kitchen gardeners had cucumber [cucumis] beds mounted on wheels which they moved out into the sun and then on wintry days withdrew under the cover of frames glazed with transparent stone." Historia Naturalis XIX. XXIII. 64 (Rackham, 1950).

Environment control. Columella recommends two methods for early production of cucumis: (1) placing containers of seedlings next to buildings that provide heat, or (2) setting plants under frames covered with lapis specularia (transparent stone). Both of Columella's methods represent environmental control. Pliny repeats the story of the specularia and associates it with the predilection of Tiberius for cucumis. The use of frames covered with transparent stone is

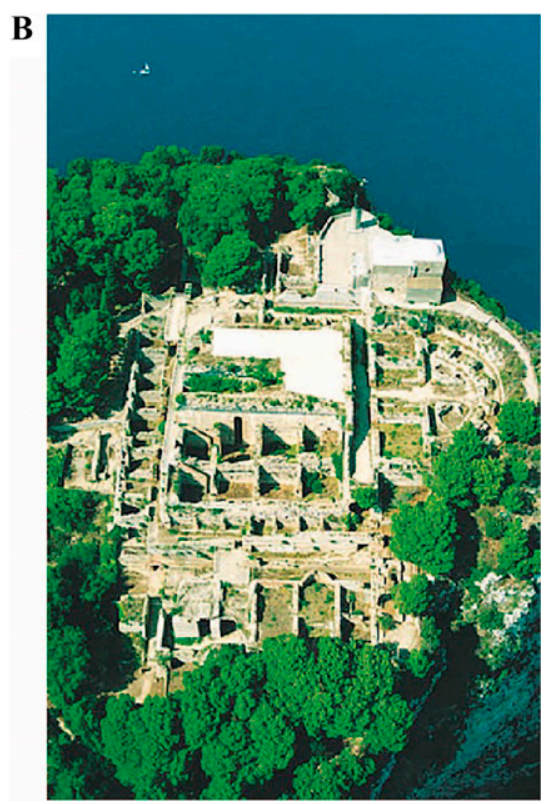

Fig. 1. (A) Bust of Tiberius Caesar (Paris and Janick, 2008). (B) Ruins of Villa Jovis on the Isle of 
A

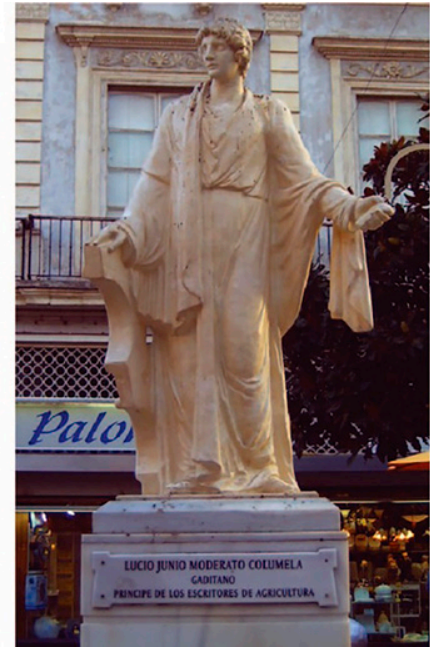

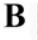

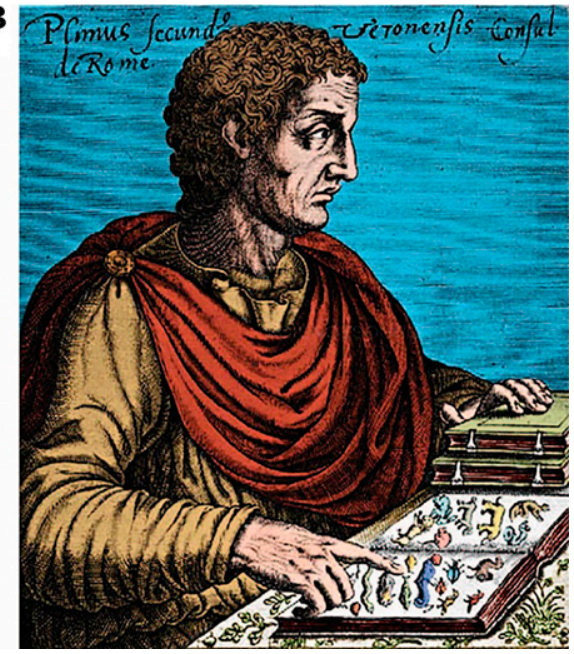

Fig. 2. (A) Statue of Lucius Columella, Cadiz, Spain. (B) Gaius Plinius Secundus (Pliny the Elder).

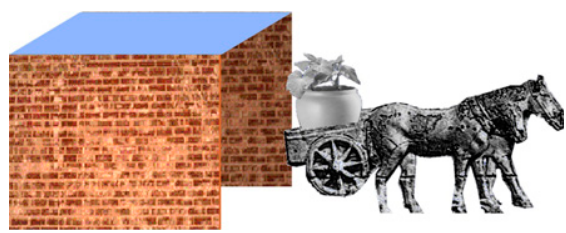

Fig. 3. A reconstruction of the specularia, Roman proto-greenhouse covered with transparent stone (lapis specularia) a translucent gypsum (selenite) that forms crystal sheets similar to mica.

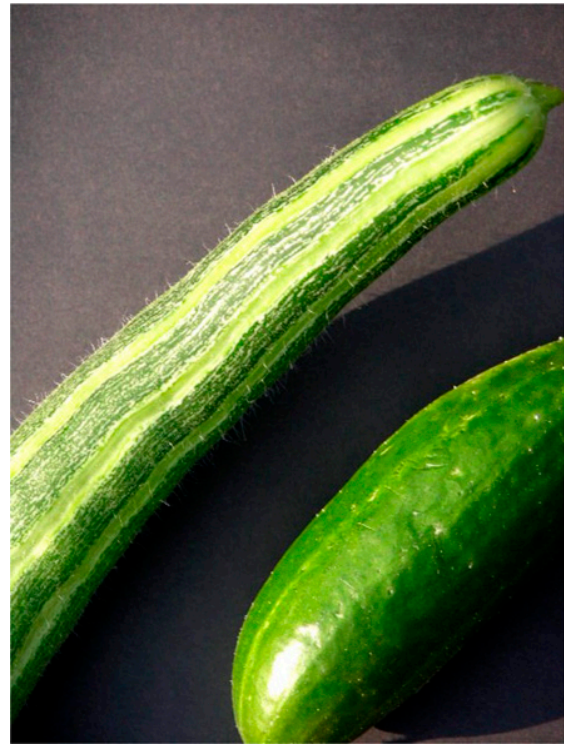

Fig. 4. Partial view of snake melon 'Striped Armenian' (left) and of Bet Alfa-type cucumber 'Shimshon' (right). Notice the presence of hairs on the snake melon and their absence on the cucumber.

a proto-greenhouse. No contemporary illustrations exist, but a suggested reconstruction of the Roman specularia is presented in Fig. 3.

Transparent stone (lapis specularia) was a variety of gypsum mined in the province of Cuenca, Spain, known as selenite, which forms transparent thin sheets, similar to mica (Serrano-Viñuelas, 2016). It was used by the Romans for skylights and window panes. Glass was known to the Romans, but there was no method to make it into sheets. The selenite sheets represent the earliest greenhouse cover. The material was later replaced by glass in the Renaissance, transparent paper in 15th century Asia, and polyethylene films in the 20th century. In the 21 st century, artificial lighting has replaced sunlight, and transparent covers are no longer required in modern vertical structures.

\section{Taxonomic Identity of the Roman Latin Cucumis}

Most modern translations of Columella and Pliny assume cucumis refers to cucumber, Cucumis sativus L., and this mistranslation is almost universal, even in contemporary literature. However, cucumber is clearly a mistranslation based on the descriptions of cucumis in Columella and Pliny (Dalby, 2003; Janick et al., 2007). In Book 10 of De Re Rustica, Columella described the cucumis as hairy (hirtus) and snake-like. Likewise, Pliny, in Book 19 of Historia Naturalis, wrote that the very young fruits of the cucumis were covered with white down (lanugine). Young melon fruits are typically pubescent, but cucumber fruits are not (Fig. 4). Also, cucumber fruits typically sport tubercles, which are not mentioned. The cucumis described by Columella and Pliny was likely the same as the sikyos of the ancient Greeks and the qishu'im of ancient Israel (Janick et al., 2007; Paris, 2015; Paris and Janick, 2010-2011), taxonomically Cucumis melo subsp. melo Flexuosus Group (L.) Naudin, the snake melon. Snake melons have been commonly grown in Mediterranean lands since ancient times, through the medieval period and to the present (Paris, 2011). Known as faqqous in that region, snake melons are presently sold as "Armenian cucumbers" in the United States. Various images of snake melons have survived from antiquity (Fig. 5; Janick et al., 2007; Avital and Paris, 2014). Pliny distinguishes between cucumis (pliable skin) and cucurbita (rind), the latter being another cucurbit, Lagenaria siceraria (Mol.) Standl., the bottle gourd. The first image of cucumber, Cucumis sativus, dates to 1335 (Fig. 6), indicative of its arrival in Europe from Asia after the fall of the Roman Empire, in the medieval period, probably by both overland and sea routes (Paris et al., 2012). The better adaptation of $C$. sativus to the cool climate of Europe is what probably led to its gradual replacing of elongate-fruited $C$. melo on that continent (Paris et al., 2011).

\section{Conclusions}

The origins of controlled-environment horticulture is the Roman specularia, which were wooden frames covered with transparent stone, a form of gypsum (selenite), known to the Romans as lapis specularia or transparent stone. The specularia was used for outof-season culture of long-fruited melons, $C$. melo Flexuosus Group. 
A
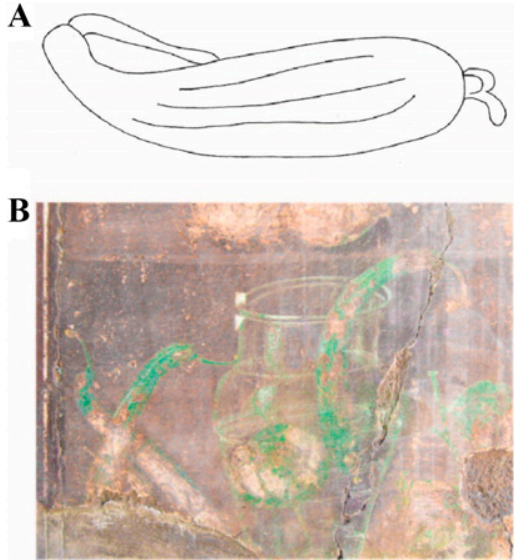

\section{C}

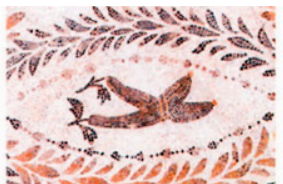

D

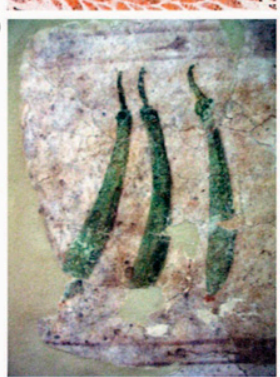

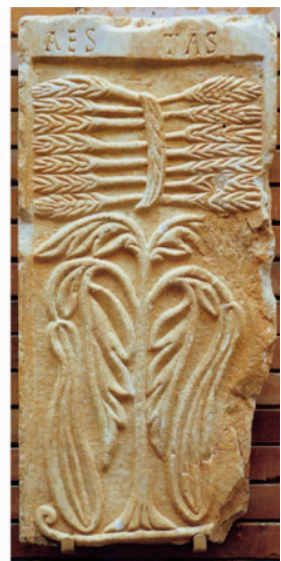

Fig. 5. Ancient mages of long-fruited cucurbits identified as Cucumis melo Flexuosus Group: (A) Egyptian Old Kingdom (1550-1300 BCE). (B) Four snake melons, one in a glass jar presumably used for pickling in the Roman town of Ercolao (Herculanum) destroyed by Mount Vesuvius in 79 CE. (C) Second century Tunisian mosaic. (D) Third century Greek tomb painting. (F) Fourth century, Merida Spain (Janick et al., 2007).

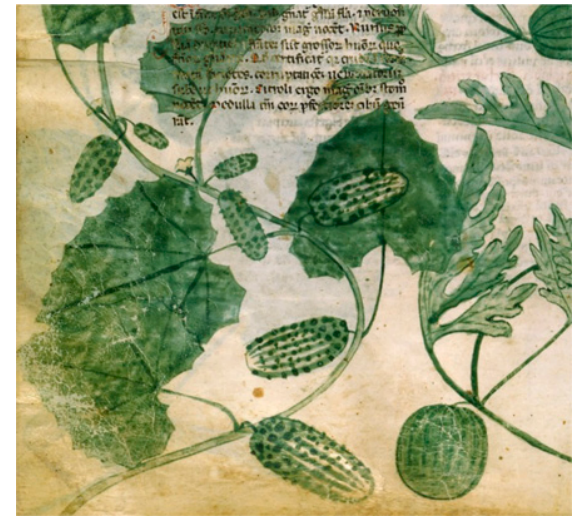

Fig. 6. Cucumber (Cucumis sativus) from the manuscript Manfred de Monte Imperiali, Pisa, Italy, ca. 1335 (Paris et al., 2011).

\section{Literature Cited}

Avital, A. and H.S. Paris. 2014. Cucurbits depicted in Byzantine mosaics from Israel, 350-600 CE. Ann. Bot. 114:203-222.

Dalby, A. 2003. Food in the ancient world from A to Z. Routledge, London, UK.

Forster, E.S. and E.H. Heffner (eds.). 1955. Lucius Junius Moderatus Columella. On agriculture and trees. Vol. 3, p. 162-163. Harvard University Press, Cambridge, MA.

Janick, J., H.S. Paris, and D.C. Parrish. 2007. The cucurbits of Mediterranean antiquity: Identifica- tion of taxa from ancient images and descriptions. Ann. Bot. 100:1441-1457, https://doi.org/ 10.1093/aob/mem242.

Paris, H.S. 2011. Semitic-language records of snake melons (Cucumis melo, Cucurbitaceae) in the medieval period and the "piqqus" of the "faqqous". Genet. Resources Crop Evol. 59:31-38.

Paris, H.S. 2015. The identity, characteristics, and vending of cucurbit crops in Israel of Roman times, p. 299-306. In: M. McWilliams (ed.).
Food \& Markets, Proceedings of the Oxford Symposium on Food and Cookery 2014. Prospect Books, London

Paris, H.S. and J. Janick. 2008. What the Roman emperor Tiberius grew in his greenhouses, $\mathrm{p}$. 33-41. Cucurbitaceae 2008, Proc. IXth EUCARPIA meeting on genetics and breeding of Cucurbitaceae. INRA, Avigon, France.

Paris, H.S. and J. Janick. 2010-2011. The cucumis of antiquity: A case of mistaken identity. Rep. Cucurbit Genet. Coop. 33-34:1-2.

Paris, H.S., J. Janick, and M.-C. Daunay. 2011. Medieval herbal iconography and lexicography of Cucumis (cucumber and melon, Cucurbitaceae) in the Occident, 1300-1458. Ann. Bot. 108:471-484.

Paris, H.S., M.-C. Daunay, and J. Janick. 2012. Occidental diffusion of cucumber (Cucumis sativus) 500-1300 CE: Two routes to Europe. Ann. Bot. 109:117-126.

Rackham, H. 1950. Pliny natural history, p. 462-463. Vol. V. Harvard University Press, Cambridge, MA.

Serrano-Viñuelas, P. 2016. The glass made of stone: Lapis specularis in the province of Cuenca. 30 Nov. 2021. <https://linkprotect.cudasvc.com/url? $\mathrm{a}=\mathrm{https} \% 3 \mathrm{a} \% 2 \mathrm{f} \% 2$ fwww.academia.edu $\% 2 \mathrm{f} 32963$ 868\%2fTHE_GLASS_MADE_OF_STONE_ LAPIS_SPECULARIS_IN_THE_PROVINCE_ OF_CUENCA\&c=E, 1,cWrULpsk1haPC3wF9ODCrUjbdxbilg7My-Zsr8xqROlg0P0T3m SNdm8V9-216x_yOzWXiHnRcpidvSMz1_ 5HsWKY17Sj4eyDbVr_Y40VGW9pP6zv0D $\mathrm{XtQ}, \&$ typo $=1>$. 